\title{
MORPHOLOGICAL STUDY OF SYNOVIAL LESIONS IN CHRONIC JOINT DISEASE
}

Abinaya Devi $A^{1}$, Lekshmi Devi P2, Sankar $S^{3}$

1 Postgraduate Student, Department of Pathology, Government Medical College, Kottayam, Kerala, India.

${ }^{2}$ Associate Professor, Department of Pathology, Government Medical College, Kottayam, Kerala, India.

${ }^{3}$ Professor and HOD, Department of Pathology, Government Medical College, Kottayam, Kerala, India.

ABSTRACT
BACKGROUND
Joint disease is a common problem, which affects all age groups. Delay in proper diagnosis may lead to inability to control the
disease process, leading to irreversible damage to the joints. Synovial biopsy is an important investigation, which is a useful
adjunct to confirm the diagnosis.

The objective of this study is to describe the morphological features of synovial biopsy specimens in various joint diseases.

\section{MATERIALS AND METHODS}

A descriptive study was conducted on 77 cases of synovial biopsy specimens received in the Department of Pathology, Government Medical College, Kottayam during a period of 18 months (May 2016 - November 2017).

\section{RESULTS}

Among 77 cases, 67 were monoarticular and 10 were polyarticular. Knee joint was the most commonly involved joint in 48 cases (62.3\%) followed by hip and ankle joint in 7 cases each (9.1\% each). Infectious arthritis (septic arthritis) with chronic joint disease was the most common lesion diagnosed (42\%) followed by Osteoarthritis (OA) (14\%), Tubercular arthritis (TBA) (12\%) and Rheumatoid arthritis (RA) (10\%). Synovial fluid was analysed in 31 cases. Among that 25 cases were infectious arthritis, 3 ca ses were OA, 1 case was RA, 1 case was TBA and 1 case was Gouty arthritis (GA). Radiological diagnosis by x-ray has got the highest sensitivity (100\%) in diagnosing Giant cell tumour (GCT), Charcot joint and GA followed by OA (90.9\%).

\section{CONCLUSION}

Infectious arthritis with chronic joint disease was the most common lesion diagnosed (42\%) followed by osteoarthritis (14\%), TBA $(12 \%)$ and RA (10\%). Synovial biopsy may give conclusive diagnosis where clinical diagnosis is equivocal.

\section{KEY WORDS}

Synovial Biopsy; Synovial Fluid Analysis; Arthritis.

HOW TO CITE THIS ARTICLE: Devi AA, Devi LP, Sankar S. Morphological study of synovial lesions in chronic joint disease. J. Evolution Med. Dent. Sci. 2018;7(27):3119-3123, DOI: 10.14260/jemds/2018/701

\section{BACKGROUND}

Joint disease is a common problem, which affects all age groups presenting in orthopaedic and rheumatology clinics. The normal joint is painless and provides wide range of movements. Failure of joint function characterised by pain, limitation of movement and instability is referred to as arthritis. It is an important cause of morbidity affecting all ages and both sexes. It may present as a monoarticular or polyarticular lesion. When synovium gets afflicted, the pattern may indicate the aetiopathogenesis. Synovial fluid is secreted into the joint cavity by the synovium, lubricates the joint and allows ease of the movement. Synovial fluid analysis often helps to differentiate inflammatory, non-inflammatory and traumatic conditions.

Synovial biopsy is an important investigation, which is a useful adjunct to correlate and confirm the diagnosis after clinical and synovial fluid evaluation. Examination of the synovial fluid should be performed before biopsy. Hence, synovial fluid analysis and synovial biopsy are routinely advised in most cases of joint disease for a definite diagnosis.

Financial or Other Competing Interest': None.

Submission 15-05-2018, Peer Review 18-06-2018,

Acceptance 23-06-2018, Published 02-07-2018.

Corresponding Author:

Dr. Lekshmi Devi P,

Associate Professor, Department of Pathology,

Government Medical College, Kottayam, Kerala, India.

E-mail: lekshmydevi@yahoo.com

DOI: $10.14260 /$ jemds $/ 2018 / 701$

\section{Objectives}

1. To describe the morphological features of synovial biopsy specimens in various chronic joint disease.

2. To describe the cytological features of synovial fluid specimens.

3. To compare the radiological diagnosis based upon x-ray findings with histopathology diagnosis.

\section{MATERIALS AND METHODS}

Type of Study

Descriptive study.

\section{Period of Study}

18 months.

\section{Study Setting}

Department of Pathology, Govt. Medical College, Kottayam.

\section{Study Population}

Samples of synovial biopsy and available synovial fluid received in the Dept. of Pathology, Govt. Medical College, Kottayam during a study period of 18 months.

\section{Sample Size}

Sample size $\mathrm{N}=4 \mathrm{pq} / \mathrm{d}^{2}$

$\mathrm{p}=$ prevalence $/$ proportion in previous study

$q=100-p$

$\mathrm{d}=$ precision/ allowable error. 
In a study conducted by Singhal et al, ${ }^{1}$ the proportion of tubercular arthritis was found to be $26 \%$

So, $\mathrm{p}=26, \mathrm{q}=74$

Taking allowable error as $10 \%$

Hence, sample size is $\mathrm{N}=4 \mathrm{pq} / \mathrm{d}^{2}$

$=4 \times 26 \times 74 / 100$

$=76.96=77$

Hence, sample size is taken as 77.

\section{Sampling Method}

Study sample includes first 77 cases of synovial biopsy specimens and available synovial fluid (open and arthroscopic) samples received in the Department of Pathology, Govt. Medical College, Kottayam during the study period of 18 months.

\section{Inclusion Criteria}

Properly labelled samples, adequate sample with radiological findings, symptoms of joint disease for a period of 6 months and above.

\section{Exclusion Criteria}

Not properly labelled sample, inadequate sample, if radiology is not available and if the symptoms are less than 6 months.

\section{Study Procedure}

Clinical details of each case will be recorded first along with radiological findings. After receiving the synovial biopsy, specimen gross examination is done. Specimens will be fixed in formalin and embedded in paraffin. $\mathrm{H}$ and $\mathrm{E}$ preparation of synovial biopsy is made and is examined. Synovial fluid is examined macroscopically. Its colour, clarity, $\mathrm{pH}$ and viscosity are noted. Dry and wet preparation of synovial fluid is made and examined. Fluid is centrifuged. Pap and Giemsa stained smears are made for cytological analysis. Crystals are seen under polarizer to diagnose crystal arthropathy. All these data are noted and entered in the proforma.

\section{Data Management and Statistical Analysis}

The data was entered in Microsoft Excel and further statistical analysis was done using SPSS software (Version 20). The statistical methods used were mean, frequency and proportion. For evaluating diagnostic accuracy of radiology based upon x-ray, sensitivity, specificity, positive predictive value and negative predictive value was calculated taking histopathology as gold standard.

\section{RESULTS}

The present study was conducted in 77 cases of synovial biopsy and 31 cases of synovial fluid received in the Department of Pathology, Government Medical College, Kottayam during a period of 18 months-

- $\quad$ Majority of the age group was between 41 and 50 years (23\%) followed by 51 and 60 years (18\%). Mean age was found to be 47.4 years.

- Among 77 cases, 42 were males (54\%) and 35 were females (45.5\%). M: F ratio was 1.2: 1.

- 42 cases $(55 \%)$ involve right side, 31 cases $(40 \%)$ involve left side and 4 cases (5\%) were bilateral. Among 4 cases of bilateral, 2 cases were RA, 1 case was $\mathrm{OA}$ and 1 case was infectious arthritis.
- 67 cases were monoarticular and 10 cases were polyarticular.

- Among 10 cases of polyarticular, 5 cases were RA, 3 cases were OA, 1 case was infectious arthritis and 1 case was non-specific arthritis.

- $\quad$ Knee joint was the most commonly involved joint in 48 cases $(62.3 \%)$ followed by hip and ankle joint in 7 cases each $(9.1 \%$ each).

- Other joints involved were the wrist joint in 4 cases (5.2\%), small joint of hand in 4 cases (5.2\%), elbow joint in 3 cases (3.9\%), shoulder joint in 3 cases (3.9\%) and small joint of foot in 1 case $(1.3 \%)$.

- Joint pain was the most common presenting complaint $(84.4 \%)$ followed by swelling of the joint $(79.2 \%)$, fever (15.6\%) and limitation of movement (26\%).

- Among 77 cases, 28 cases had symptoms for 6 months, 40 cases had symptoms for $>6$ months to 1 year and 9 cases had symptoms for more than 1 year.

- Infectious arthritis (septic arthritis) with chronic joint disease was the most common lesion diagnosed (42\%) followed by osteoarthritis (14\%), TBA (12\%) and RA (10\%).

- There were 3 cases of PVNS, 3 cases were synovial osteochondromatosis, 3 cases were GCT, 1 case of Charcot joint and 1 case of GA.

- In 6 cases, the exact cause of arthritis could not be found out and were classified as chronic non-specific arthritis.

- $\quad$ RA was observed more commonly between $4^{\text {th }}$ and $7^{\text {th }}$ decades. OA was observed between $4^{\text {th }}$ and $7^{\text {th }}$ decades. TBA was observed both in younger and older age group.

- Synovial fluid was analysed in 31 cases. Its physical and cytological properties were studied. Among that 25 cases were infectious arthritis, 3 cases were $0 A, 1$ case was RA, 1 case was TBA and 1 case was GA.

- In case of gouty arthritis, the microscopy showed needle shaped crystals which was negative for birefringence on polarisation indicating monosodium urate crystals.

- Synovial lesions were categorised into three groups as Group 1, Group 2 and Group 3 based upon the nature and severity of inflammation in synovial fluid.

- Group 1 is non-inflammatory group which includes OA, Charcot joint and PVNS. Group 2 is mild-to-moderate inflammatory group which includes TB, RA, GA and chronic non-specific arthritis and Group 3 is severe inflammatory group which includes infectious arthritis (septic arthritis).

- $\quad$ In Group 1 there were 3 cases, Group 2 there were 3 cases, Group 3 there were 25 cases.

- On the basis of x-ray, radiological diagnosis was obtained. Among that 38 cases $(49.4 \%)$ were infectious arthritis, 14 cases $(18.2 \%)$ were 0 A, 12 cases $(15.6 \%)$ were TBA, 5 cases $(6.5 \%)$ were RA, 3 cases $(3.9 \%)$ were GCT, 2 cases $(2.6 \%)$ were synovial osteochondromatosis, 1 case $(1.3 \%)$ was Charcot joint, 1 case was $(1.3 \%)$ PVNS and 1 case $(1.3 \%)$ was GA.

- While comparing the diagnostic accuracy, radiology has got the highest sensitivity (100\%) in diagnosing GCT, Charcot joint and Gouty Arthritis followed by OA (90.9\%). But in case of PVNS sensitivity was only $33 \%$, in RA it was $62.5 \%$ and in OCM it was $66.6 \%$. This indicates that in some joint diseases, only $\mathrm{x}$-ray findings will not 
aid in the diagnosis. In such cases, MRI may be done which is more sensitive.

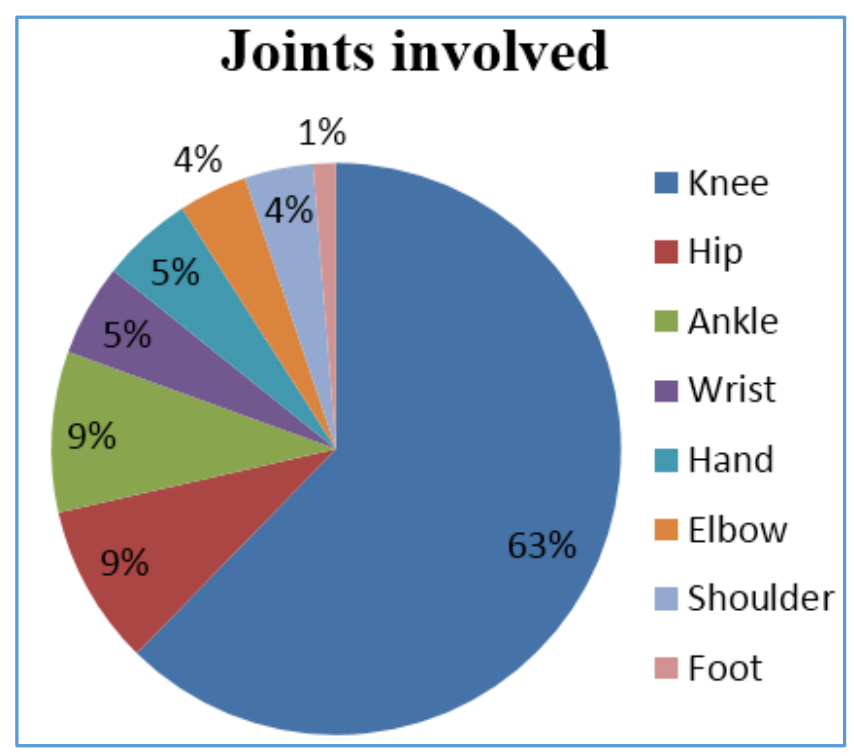

Figure 1. Proportion of various Joints Involved

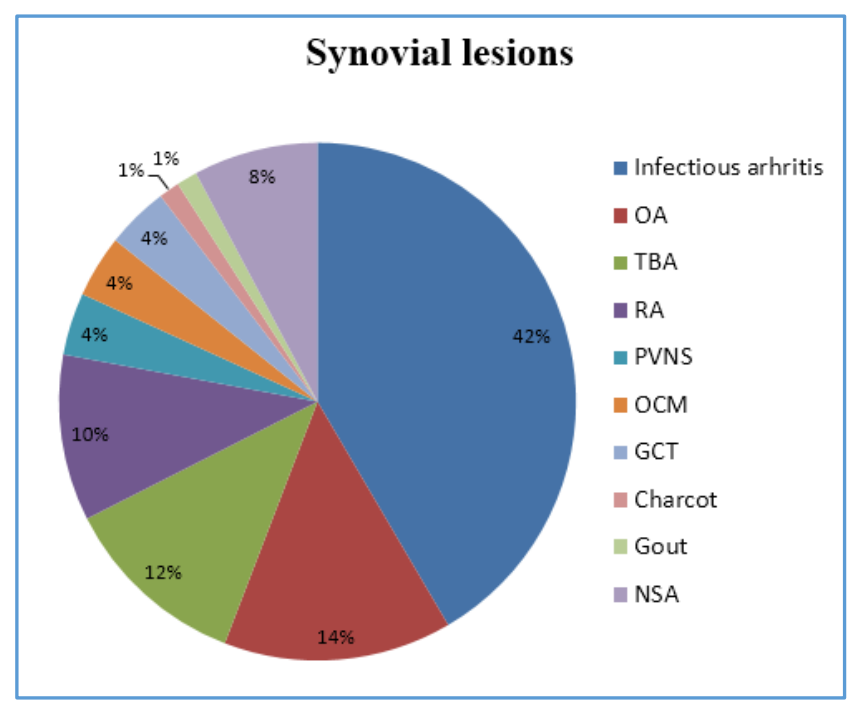

Figure 2. Proportion of various Synovial Lesions

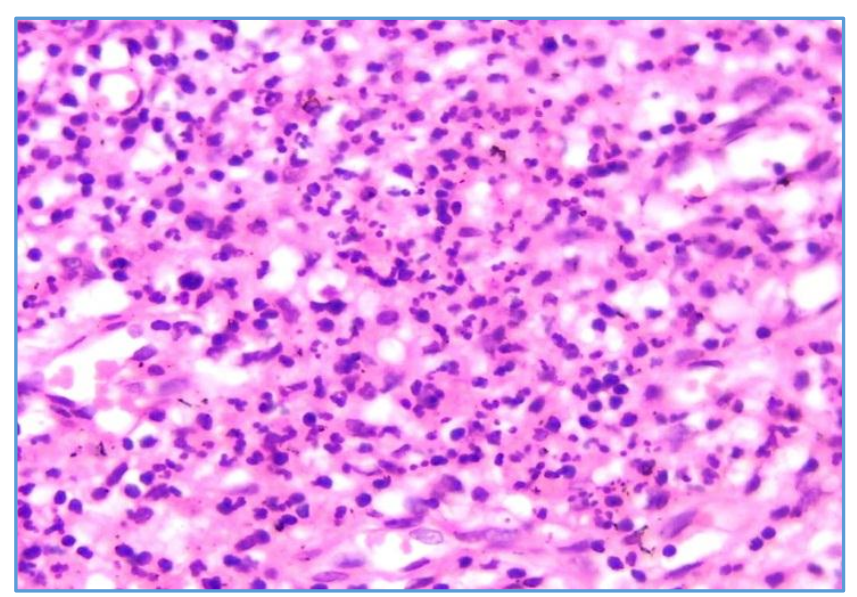

Figure 3. Photomicrograph of

Septic Arthritis 40X (H and E)

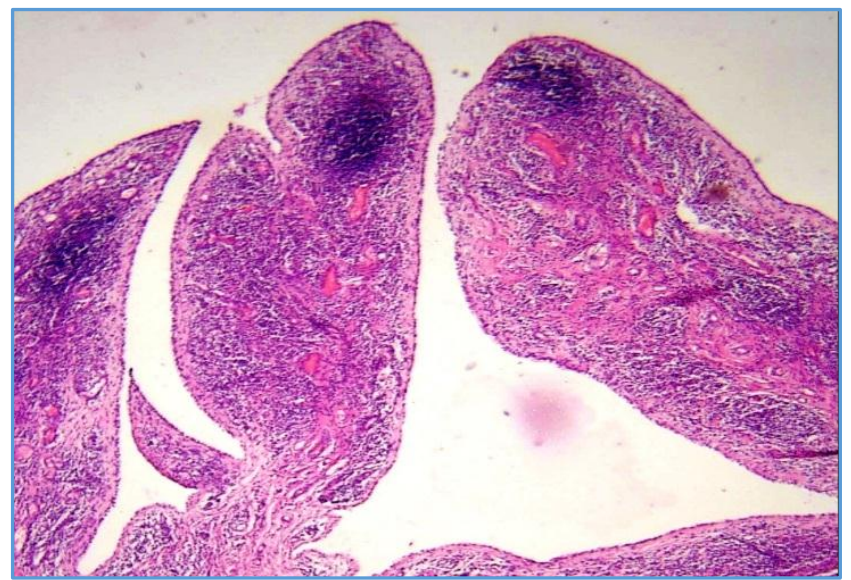

Figure 4. Rheumatoid Arthritis- $H$ and $E(4 X)$ showing Villous Hyperplasia of Synovium, Pannus Formation and Lymphoid Follicles

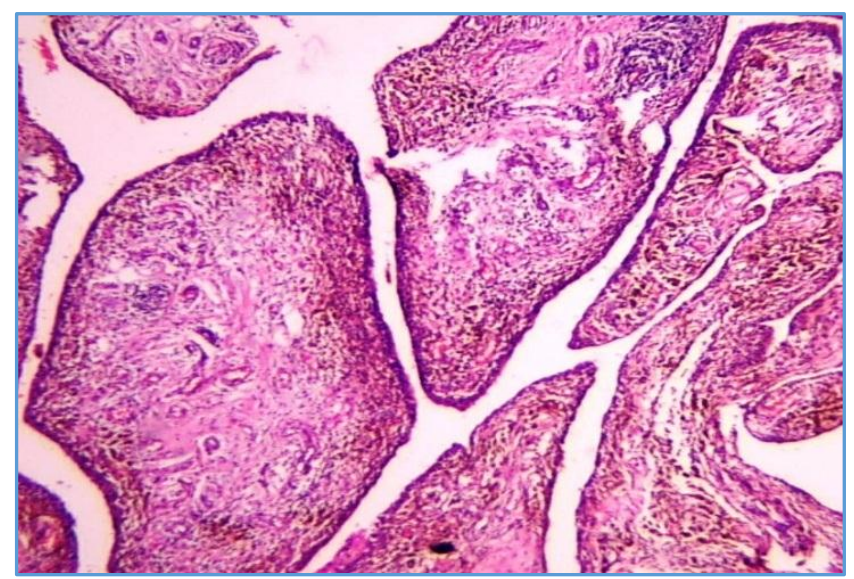

Figure 5. Pigmented Villonodular Synovitis- H and E (4X) shows Synovial Hyperplasia and Hemosiderin-Laden Macrophages

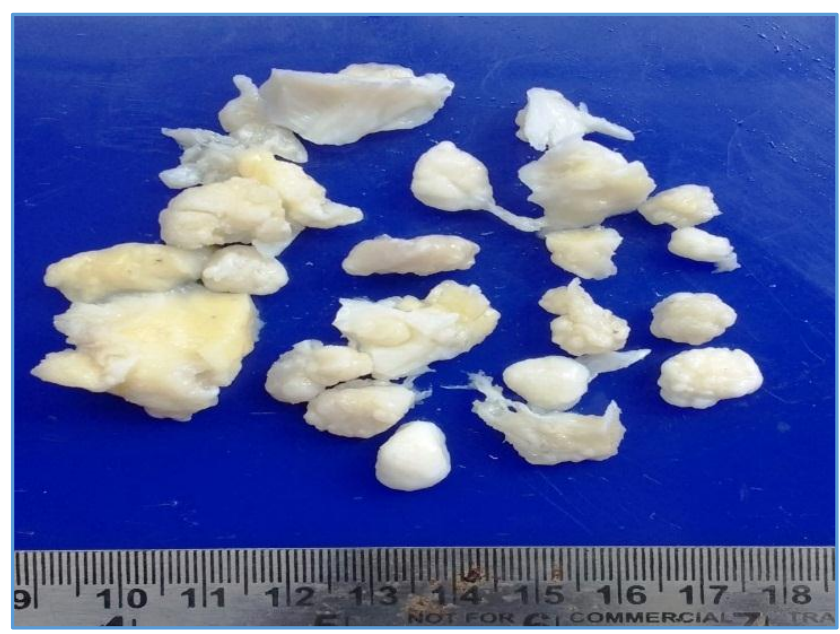

Figure 6. Shows Multiple Whitish Loose Bodies in Synovial Osteochondromatosis 


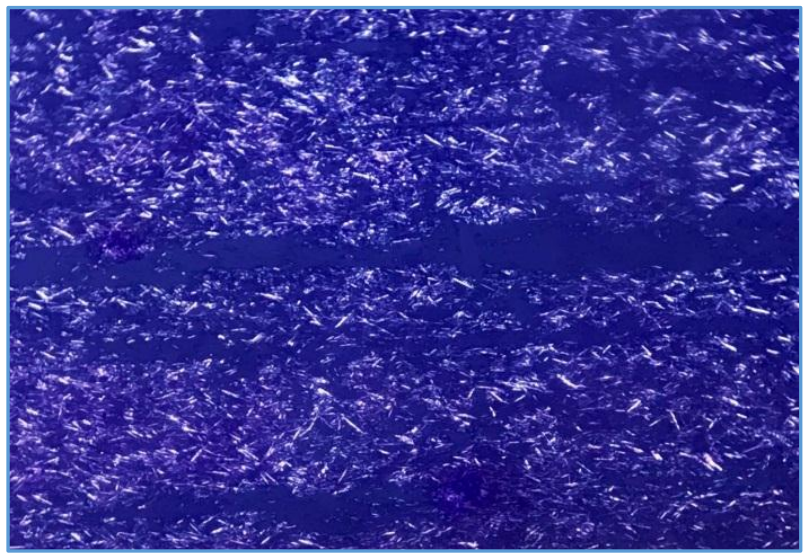

Figure 7. Gouty Arthritis- Crystals showing Negative Birefringence on Polarisation

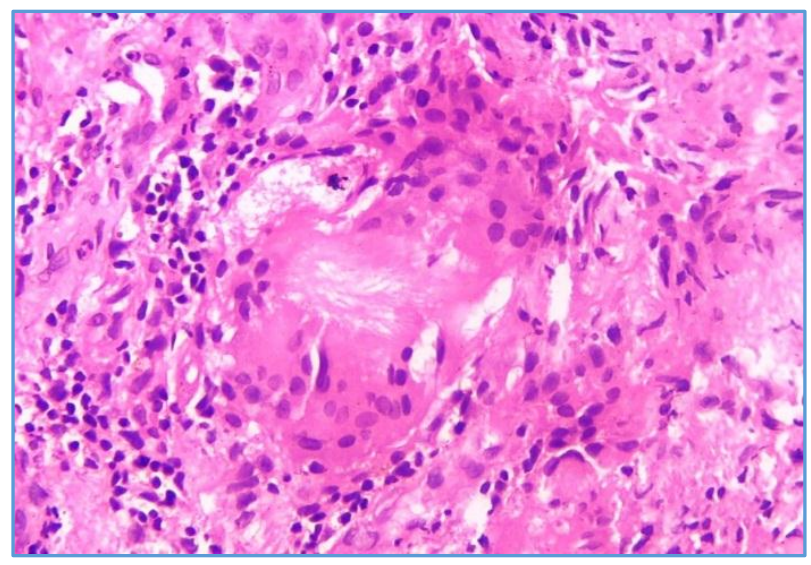

Figure 8. Gouty Arthritis $\mathrm{H}$ and $\mathrm{E}$ (40X) showing Pale Needle-Shaped Crystals surrounded by Foreign Body Granulomatous Reaction

\section{DISCUSSION}

Synovial biopsy is an important useful investigation adjunct to correlate and confirm the diagnosis made after clinicoradiological and synovial fluid evaluation. At times synovial biopsy alone gives the conclusive diagnosis. The present study was conducted on 77 cases of synovial biopsy and 31 cases of synovial fluid received in the Department of Pathology, Government Medical College, Kottayam during the study period of 18 months from April 2016 to September 2017. Clinical, radiological and synovial fluid findings were correlated for arriving at the specific diagnosis of synovial lesions. But in 6 cases the exact diagnosis could not be arrived and hence classified as chronic non-specific arthritis.

In the present study of 77 cases of synovial biopsy, we found that the age of the patients presenting with various joint symptoms was ranging from 12 to 74 years with mean age of 47.4 years. It is comparable with the study conducted by Venkataraman et al $^{1}$ in 2015 on 50 cases of joint disease, which showed the age group ranging from 13 to 63 years.
Another study by Qazi Najeeb et $\mathrm{al}^{2}$ showed age group between 16 and 75 years.

In the present study males were more commonly affected than females, which is comparable with the study by Venkataraman et al. M: F ratio was 1.2: 1 in the present study, which is comparable with the study by Vijay PM et al $^{3}$ in which $\mathrm{M}$ : $\mathrm{F}$ ratio was $1: 0.6$.

In the present study, monoarticular joint involvement was more common than polyarticular joint involvement which is comparable with the studies by Singhal et $\mathrm{al}^{4}$ and Venkataraman et al on 50 cases of joint diseases.

In the present study, knee joint was the most commonly involved joint followed by hip and ankle joint which is comparable with the studies by Venkataraman et al, Vijay PM et al and Singhal et al. The most common presenting symptom was pain and swelling, which is comparable with the study by Vijay PM et al.

The distribution of cases between the present study and other studies were shown in the following table.

\begin{tabular}{|c|c|c|c|c|}
\hline & & $\begin{array}{c}\text { Present } \\
\text { Study }\end{array}$ & $\begin{array}{c}\text { Singhal } \\
\text { et al } 4\end{array}$ & $\begin{array}{c}\text { Venkataraman } \\
\text { et al1 }\end{array}$ \\
\hline $\begin{array}{l}\text { Sl. } \\
\text { No. }\end{array}$ & Diagnosis & $\begin{array}{c}\text { No. of } \\
\text { Cases } \\
(\%)\end{array}$ & $\begin{array}{c}\text { No. of } \\
\text { Cases } \\
(\%)\end{array}$ & $\begin{array}{c}\text { No. of Cases } \\
\text { (\%) }\end{array}$ \\
\hline 1 & $\begin{array}{l}\text { Infectious arthritis } \\
\text { (IA) }\end{array}$ & $32(41)$ & $3(6)$ & $2(4)$ \\
\hline 2 & Osteoarthritis (OA) & $11(14)$ & $3(6)$ & $4(8)$ \\
\hline 3 & $\begin{array}{c}\text { Tubercular arthritis } \\
\text { (TBA) }\end{array}$ & $9(12)$ & $13(26)$ & $8(16)$ \\
\hline 4 & $\begin{array}{c}\text { Rheumatoid arthritis } \\
\text { (RA) }\end{array}$ & $8(10)$ & $14(28)$ & $6(12)$ \\
\hline 5 & $\begin{array}{c}\begin{array}{c}\text { Pigmented } \\
\text { villonodular synovitis } \\
\text { (PVNS) }\end{array} \\
\end{array}$ & $3(4)$ & $1(2)$ & $1(2)$ \\
\hline 6 & \begin{tabular}{c|c|} 
Synovial \\
osteochondromatosis \\
\end{tabular} & $3(4)$ & - & - \\
\hline 7 & $\begin{array}{c}\text { Giant cell tumour } \\
\text { (GCT) }\end{array}$ & $3(4)$ & - & - \\
\hline 8 & Charcot joint (CJ) & $1(1)$ & - & $1(2)$ \\
\hline 9 & Gouty arthritis (GA) & $1(1)$ & $2(4)$ & $1(2)$ \\
\hline 10 & $\begin{array}{c}\text { Non-specific arthritis } \\
\text { (NSA) }\end{array}$ & $6(7)$ & $10(20)$ & $16(32)$ \\
\hline 11 & Traumatic arthritis & - & $4(8)$ & $4(8)$ \\
\hline & Total (No. of Cases) & 77 & 50 & 50 \\
\hline
\end{tabular}

In the present study, infectious arthritis with chronic joint disease was more common when compared to other studies. This could be due to the reason that the patients will be more symptomatic during acute phase and seek medical attention initially at that time only.

Synovial fluid findings were compared with the studies by Venkataraman et al and Qazi Najeeb et al.

\begin{tabular}{|c|c|c|c|c|}
\hline Diagnosis & Cytology & Present Study & Venkataraman et al1 & Qazi Najeeb et al $^{2}$ \\
\hline Infectious arthritis & Colour/ clarity & Yellow/ opaque & Yellow/ turbid & Turbid \\
\cline { 2 - 5 } & TC (cells/mm) & $10,000-90,000$ & 26,000 & $60,000-90,000$ \\
\cline { 2 - 5 } & Predominant cell (\%) & Neutrophils (>90) & Neutrophils (90) & Neutrophils (95) \\
\hline \multirow{2}{*}{ OA } & Colour/ clarity & Straw/ clear & Pale yellow/ clear & Clear \\
\cline { 2 - 5 } & TC (cells/mm) & $500-1000$ & $200-500$ & $150-1800$ \\
\cline { 2 - 5 } & Predominant cell (\%) & Lymphocytes (80) & Neutrophils & Lymphocytes (60) \\
\hline
\end{tabular}




\begin{tabular}{|c|c|c|c|c|}
\hline \multirow{3}{*}{ RA } & Colour/ clarity & Yellow/ transparent & Yellow/ cloudy & Clear \\
\cline { 2 - 5 } & TC (cells/mm) & 7500 & $7600-8500$ & $3000-20,000$ \\
\cline { 2 - 5 } & Predominant cell (\%) & Neutrophils (50) & Neutrophils & Neutrophils (86) \\
\hline \multirow{3}{*}{ TBA } & Colour/ clarity & Straw/ turbid & Yellow/ turbid & Turbid \\
\cline { 2 - 5 } & TC (cells/mm) & 8000 & $6000-12000$ & $1500-4500$ \\
\cline { 2 - 5 } & Predominant cell (\%) & Neutrophils (60) & Neutrophils & Neutrophils (70) \\
\hline
\end{tabular}

Based on synovial fluid findings in 31 cases they were classified into 3 groups, which were compared with the other studies in the following table.

\begin{tabular}{|c|c|c|c|}
\hline Groups & $\begin{array}{c}\text { Present Study } \\
\mathbf{( \% )}\end{array}$ & $\begin{array}{c}\text { Singhal } \\
\text { et } \mathbf{a l}^{\mathbf{4}} \mathbf{( \% )}\end{array}$ & $\begin{array}{c}\text { Venkataraman } \\
\text { et al } \mathbf{1}(\mathbf{\%})\end{array}$ \\
\hline Group 1 & 10 & 16 & 23 \\
\hline Group 2 & 10 & 78 & 72 \\
\hline Group 3 & 80 & 6 & 5 \\
\hline Table 3. Comparison of Group distribution with Other \\
Studies \\
\hline
\end{tabular}

This disparity is due to the predominance of infectious arthritis (group 3) in the present study.

In the present study diagnosis of infectious arthritis by radiology has a specificity of $73 \%$, which is comparable with $74 \%$ in a study by Rabin DN et al. 5

Diagnosis of OA by radiology showed sensitivity of $90.9 \%$ and specificity of 93.9, which is comparable with the sensitivity of $91 \%$ and specificity of $86 \%$ in a study by Altman R et al. 6

In the present study radiology shows $100 \%$ specificity in diagnosing Gouty Arthritis, which is comparable with the specificity of $93 \%$ in a study by Rettenbacher et al. ${ }^{7}$

In RA, x-ray has got low sensitivity of only $63 \%$. This is due to the fact that $\mathrm{x}$-ray lacks sensitivity in detecting early rheumatoid arthritis. MRI is more sensitive than conventional radiology in the detection of early RA. ${ }^{8}$

\section{Limitations of the Present Study}

1. Non-availability of synovial fluid in all cases.

2. Out of 77 cases 6 cases were chronic non-specific, where the exact reason for arthritis could not be found out.

3. Short study period and inability to follow-up the cases.

\section{CONCLUSION}

1. Infectious arthritis (septic arthritis) with chronic joint disease was the most common lesion diagnosed (42\%) followed by osteoarthritis (14\%), TBA (12\%) and RA $(10 \%)$.

2. Synovial fluid was analysed in 31 cases. Among these cases, 25 cases were infectious arthritis, 3 cases were
OA, 1 case was RA, 1 case was TBA and 1 case was GA. It helps to distinguish inflammatory and non-inflammatory arthritis.

3. Radiological diagnosis based on $\mathrm{x}$-ray was found to have $100 \%$ sensitivity in diagnosing GA, GCT and Charcot joint followed by OA (90.9\%). But in case of PVNS sensitivity was only $33 \%$, in RA it was $62.5 \%$ and in synovial chondromatosis it was $66 \%$. In such cases, MRI will be more sensitive.

\section{REFERENCES}

[1] Venkataraman M, Sathyadharan P. Role of needle synovial biopsy in joint diseases. J Evol Med \& Dental Sciences 2015;4(44):7626-34.

[2] Najeeb Q, Aziz R, Hamid S, et al. An analysis of Different types of Arthritis with joint effusions among Kashmiri population in a tertiary care hospital. Int J of Biomedi Res 2015;6(4):274-8.

[3] Vijay PM, Doddikoppad MM. Clinicopathological study of inflammatory synovial lesions. Int J Biol Med Res 2011;2(4):882-8.

[4] Singhal O, Kaur V, Kalhan S, et al. Arthroscopic synovial biopsy in definitive diagnosis of joint diseases: an evaluation of efficacy and precision. Int J Appl Basic Med Res 2012;2(2):102-6.

[5] Rabin DN, Smith C, Kubicka RA, et al. Problem prostheses: the radiologic evaluation of total joint replacement. Radiographics 1987;7(6):1107-27.

[6] Altman R, Asch E, Bloch D, et al. Development of criteria for the classification and reporting of osteoarthritis. Classification of osteoarthritis of the knee. Diagnostic and Therapeutic Criteria Committee of the American Rheumatism Association. Arthritis Rheum 1986;29(8):1039-49.

[7] Rettenbacher T, Ennemoser S, Weirich $\mathrm{H}$, et al. Diagnostic imaging of gout: comparison of highresolution US versus conventional X-ray. Europe Radiol 2008;18(3):621-30.

[8] Sugimoto H, Takeda A, Masuyama J, et al. Early-stage rheumatoid arthritis: diagnostic accuracy of MR imaging. Radiology 1996;198(1):185-92. 